\title{
Higher Education Social Studies Curricula And Their Implementations in Indonesia and Japan
}

\author{
Umi Chotimah \\ Social Studies Departement \\ Sriwijaya University \\ Palembang, Indonesia \\ nasya.afif@gmail.com \\ Farida \\ Social Studies Departement \\ Sriwijaya University \\ Palembang, Indonesia \\ hjumich@gmail.com
}

\author{
Riswan Jaenudin \\ Social Studies Departement \\ Sriwijaya University \\ Palembang, Indonesia \\ riswanjaenudin@ymail.com
}

Eiji Fujita

Faculty of Education

Kochi University

\begin{abstract}
This study aims to describe the concept of curriculum applied in Social Studies (SS) Department, Faculty of Teacher Training and Education (FTTE), Sriwijaya University (SU), Indonesia and Faculty of Education (FE) Kochi University (KU), Japan, the overview of its implementation, as well as students' and lecturers' perceptions, and to figure out the possibility of problems in the implementation. The population of this study is all of lecturers and students at 3rd, 5th, 7th, 9th semester (total 928 students) SU, Indonesia and 5 lecturers and 24 students of FE, KU, Japan. Data were collected using documentation, observation, and questionnaires. The qualitative data were analyzed using descriptive qualitative data analysis techniques: data reduction, data presentation. Data from the questionnaire were analyzed using quantitative data in the form of proportion and mode. The results show some similarities and differences between both departments. They have similarities in history and economy but the differences in history are divided into 3 groups: Japanese, Oriental, and Western. The differences also include Geography and Topography, Jurisprudence and Political, Sociology, Economic and Political Economy, and Philosophy. Furthermore, all students in FE, KU have to study about social studies in the primary, secondary, and high school curriculum. In an implementation, the similarities cover media of learning, the engagement of power point and numbers of lectures, fourteen times. Moreover, the differences in this area that every student must have a textbook and they have to learn by reading the book while the lecturer is teaching. Percentages of having similarities of students and lecturer perception about social studies curriculum are between $49-60 \%$, among which are social studies aims to make students be a good citizen, social studies are necessary for all students, social studies courses should be made fun, and so on.
\end{abstract}

Keywords-Higher Education, Social Studies Curricula, Implementation

\section{INTRODUCTION}

Social Studies are a field of studies which discuss the social life in a community. They examine various issues related to human life as social beings taken from social lives using social science concepts, which are used for the benefit of learning in schools. Given the conditions and social development of society, and changing along with the times, it will certainly affect the SS. Dynamics that occur in various areas of social life should be properly addressed and taken into consideration by the social studies curriculum developers, as well as educational institutions in generating social studies curriculum. The curriculum serves as a guide for teachers in implementing the learning process.

As a field of social science taught at the college level, Social Studies refers to the organization of curriculum and lesson materials that aim to develop students' skills through social and cultural knowledge. In this case, the main focus is the Social Studies which address human relationships in society and the environment. The curriculum aims to educate students to develop the ability to think, to develop attitudes, and values for themselves as individuals, as well as social and cultural beings. "The major goal of the social studies is to prepare citizens who can make-reflective decision and participate successfully in the civic life of their communities, nation, and the world. There are four categories contributing to the major goal: knowledge, skills, attitudes, and citizen action [1].

The concept of social studies is interpreted differently. Ref. [1] states that: the Social Studies are the part of the elementary and high school curricula having the primary responsibility for helping students to develop the knowledge, skills, attitudes, and values needed to participate in the civic life of their local communities, the nation, and the world. Meanwhile, Ref. [2] states that Social studies are the integrated study of the social sciences and humanities promoting civic competence. Within the school program, social studies provide coordinated, systematic study description upon disciplines such as anthropology, archeology, economics, geography, history, law, philosophy, political science, psychology, religion, and sociology, as well as appropriate contents from the humanities, mathematics and natural sciences.

Social studies are most commonly recognized as the name of a course or set of courses taught in primary and secondary 
schools or elementary, middle, and secondary schools, but may also refer to the study of aspects of human society at certain post-secondary and tertiary schools around the globe. Many such courses are interdisciplinary and draw upon various fields, including sociology, political science, history, economics, religious studies, geography, psychology, anthropology, and Civics. At Harvard University, social studies are offered as an undergraduate major. At the elementary school level, social studies generally focus first on the local community and family. In middle and high school, the social studies curriculum becomes more discipline-based and content-specific. Social studies as a subject vary greatly between countries and the curricula are not synonymous with the name of the sciences, whereas others are created independently for schools. This subject appears in different countries' syllabus with a similar content but in different names. An example is a subject of Liberal Studies or the former Integrated Humanities in Hongkong.

There are a variety of dimensions of education in Indonesia. Social Studies called Ilmu Pengetahuan Sosial (IPS)are usually developed in the academic curriculum or curriculum discipline. Such a curriculum would be labeled as disciplines, programs or subjects. The objective is closely related to the purpose of disciplines and is usually applied to secondary and higher education [3], [4]. Based on such understanding of Social Studies Social Sciences Education, it can be a field of study that examines the reality and human behavior problems or problems of human relationships.In other words, the term Social Science Education in Indonesia is similar to the "Social Sciences" and "Social Science Education".[4], [5]. To the level of basic education (Primary School/Islamic Elementary or and Junior High School), social studies curriculum in the form of integrated curriculum is a combination of several subjects which are economics, history, geography. As for the secondary education level, social studies curriculum is "separated curriculum" consisting of history, geography, economics, and sociology. Thus, the term Social Sciences Education covers a broader sense, is not limited to schooling curriculum but include social studies education programs in the community. In high school curriculum 1975 to the curriculum in 1994, the term IPS is used as a name that distinguishes IPS majors with majors Natural Sciences (IPA) and the Department of Languages. The diversity of the terms used is closely related to that of educational programs to the level and type of educational institution that has specific institutional objectives for each level and type of education [6]. Social Studies Education (SSE) or Ilmu Pengetahuan Sosial (IPS) term is used by the developers at universities as proposed by [7], that in college IPS is similar to the term "Social Studies" in the tradition of American education. In addition, PIPS is used as the name of the course, department name, or the name of the faculty at the Institute of Education in the form of the Institute of Teacher Training and Education (or the College of Teacher Training and Education, or Faculty of Teacher Training and Education. PIS terms set forth in order to develop the curriculum in colleges and programs in the Graduate IPS.

In the Faculty of Teacher Training and Education (FTTE) Sriwijaya University (SU), PIPS department was established in $1983 / 1984$. It is in charge of three study programs namely
Economics Studies, History and Pancasila and Civic Education. Its vision is to be superior and competitive Education Department of Social in human resource development, research, technology, and information".

The relationship between nations of the world cannot be separated from one another, such as negotiating with various nations for the sake of their own national interests. Similarly, the relationship between Indonesia and Japan, both as a nation and as a relationship among the people. Historically, the relationship between both nations has existed since the 13th century. Indonesia as part of Southeast Asia has also become an important part of the objectives of the Japanese people seeking a new life. Their position here equated with other foreign nation East Asia by the Dutch, this gives them a great chance to develop themselves, especially in the field of trade.

\section{A. Curriculum Concepts and Components}

There are different curriculum definitions according to the experts, including by [8], [9]. From the various definitions, it appears that the notion of curriculum is very diverse, from the simplest to the most complex. All of it is due to the different backgrounds, in accordance with the flow or educational theory espoused. However, any sense of the curriculum, in essence, concerns ideas, documents, processes, and results. In other words, the curriculum can be seen as an idea, as a written plan, as an activity (process) and as a result of an idea [5].

The curriculum as an idea generated through curriculum theory as an idea, through the theories and research, particularly in the areas of curriculum and education. Furthermore, the curriculum as a written plan, as the realization of the curriculum as an idea includes the goals, materials, activities, tools, and time. The curriculum as an activity is an implementation of a written plan; in the form of instructional practice. Another is the curriculum as a result is a consequence of the curriculum as an activity, in the form of achievement of the curriculum objectives, namely the achievement of behavior/abilities of the learners.

Ref. [10] suggested that a curriculum usually consists of anatomical components or elements, namely: (1) aims, goals and objectives; (2) the subject matter or content; (3) learning activities; and (4) evaluation. In other words, curriculum contains four basic components, namely the objectives, content, process, and evaluation.

\section{B. Social Studies Concepts}

Social Studies Education (SSE) in Indonesia is conceptually not separated from an understanding of Social Studies. Thus, the Social studies is a discipline derived from the social sciences, which was developed to meet the objectives of education/learning, both levels of schooling and higher education. In addition, in accordance with its objectives, it is necessary for the selection of the various aspects of each discipline of the social sciences. Social Studies objectives are: Social Studies programs have a responsibility to prepare young people to identify, understand, and work to solve problems that face our nation and interdependence increasingly diverse world. Over the past Several Decades, the professional consensus has been that such programs ought to include goals in the broad areas of knowledge, democratic values, and skills. 
Programs that combine the acquisition of knowledge and skills with the application of democratic values to life through social participation present an ideal balance in social studies. It is essential that major Reviews These goals Be Viewed as equally important. The Relationship Among the knowledge, values, and skills is one of mutual support [11].

The purpose of Social Studies for the 21st century is still putting the process of civic education, the development of "civic responsibility and active civic participation" as one of its substance. The other aspects the development of social skills with regard to the vision of his life experiences, critical understanding of the social sciences, human understanding in the context of unity in difference, and critical analysis of the state of human life. What educational purposes IPS in Indonesia? It turns out that it is also related to the sense and purpose of the social studies.

SSE purposes in Indonesia include aspects of knowledge and understanding, values and attitudes, and skills aspects. IPS education aims to develop students' skills through social and cultural knowledge. Its main focus is to learn about human relationships in society and the environment. Automatically, the curriculum goal is to educate students to develop the ability to think, attitudes, and values for themselves as individuals and as social and cultural beings. Meanwhile, the notion of education as a social studies sciences has implications for the name subjects or subjects. In secondary education and higher education, the reality points to include the subjects such as history, economics, geography, anthropology, sociology, and statecraft.

Based on the above, the learning of social studies education in primary and secondary education, and higher education aims to make students able to: be a good citizen, behave in accordance with the values and norms that exist in society, have a good self-concept, helps introduction and appreciation of the global community and multi-cultural composition, the socialization process of social, economic, political, understand the past and present as a basis for making / taking a decision, have the basic ability to think logically and critically, curiosity, inquiry, problem solving, and skills in social life, have the commitment and awareness of social values and humanity, to participate actively in community life so that students are proud of being Indonesian, and has the ability to communicate, collaborate and compete in a pluralistic society, at the local, national, and global [1].

There are two concepts in the education system in Indonesia. First, IPS Education aimed at the world of schooling. Secondly, Education Discipline Social Sciences for college. In the first part, is the effort of selecting and organizing scientific and psycho-pedagogical of social sciences, humanities, and other disciplines that are relevant for the purpose of professional education social studies teacher. Meanwhile, the SSE for the college, known as Workforce Education Institutions, social studies teacher is a strategic effort to build human in welcoming the era of globalization. For that, it needs painstaking efforts to instill character high discipline, perseverance, solid, responsible, and sincerity in devotion [12].

SSE for learning in school is divided into two versions or traditions, namely, first, in the tradition of citizenship education, IPS transmission, which consists of subjects Pancasila and CivicsEducation, and History of Indonesia; second, education in the tradition of social science IPS with Integrated Social Science subjects for elementary school and Islamic Elementary School, SS for Junior High School and Islamic Junior High School, and SS-separated for Schools and Islamic Senior High School, also vocational. Both of these concepts are in an effort to achieve the vision of Indonesian human development and Law No. 20 The year 2003 on National Education System. It is stated that education is a process of learning and empowerment in a democratic and fair, multi-meaning education, and education by example, where builders will develop creativity.

Kochi University is one of the universities in Japan that has a good cooperative relationship in the field of education with Sriwijaya University and has a faculty of education that one of the subjects in curriculum development. One of its fields is Social Studies Education (SSE). SSE consisting of History, Geography, Economics, Philosophy, and Law. Therefore, SSE Departement, FTTE, Sriwijaya University did collaborative research with $\mathrm{KU}$ with the following research questions: 1) What are the concepts of implementing a social studies curriculum at the FTTE, Sriwijaya University in Indonesia and FE, Kochi University in Japan? b). how do the two Faculties reviews their social studies curricula? c). What are the students' perceptions about the implementations of social studies curricula at both universities?

\section{METHOD}

This research was conducted by SSE department, FTTE, Sriwijaya University,Indonesia and FE Kochi University, Kochi-Japan. The population of this study was all of lecturers and students on $3 \mathrm{rd}$, 5th, 7th, 9th semester (total 928 students) SU, Indonesia and 5 lecturers and 24 students of FE, KU,Japan. The data collected using documentation, observation, and questionnaires. The data were analyzed using descriptive qualitative data analysis techniques for qualitative data in the form of data reduction, data presentation, while the questionnaire data will be analyzed using quantitative data in the form of proportion and mode.

\section{RESULTS AND DISCUSSION}

Due to the components of the curriculum, this part will be discussed on the basis of purposes, content or subject matters, learning activities, and evaluation.

The purpose of social studies curricula in FTTE, Sriwijaya University, is to become one of the most excellent and competitive SSE Department in human resource development, research, technology, and information". Its missions are 1) implementing a quality education to produce the professional social sciences teachers (who master technology and information, and can compete globally, 2) developing research in the field of social sciences education and which result in the information technology and social science education reform, 3) implementing the improvement of the quality of education social sciences in accordance with the development and needs of the community.

The content of SSE Department, FTTE, SU in accordance with (Regulation of National Education Minister 232/U/2000); 
shown in the structure of curriculum 2014, Regulation of National Education Minister 232/U/2000); shown in the structure of curriculum 2014, Regulation of National Education Minister 045/U/2002.Furthermore, considering that Social Studies Department is divided into three study programs, then the vision, mission, and majors above are also divided into objectives, vision, and mission in each study program. The mission was developed and predicted to the needs of graduate users over the next five years, namely 2025, in accordance with the vision of economic education study program, history education study program and civics education study program. Then, the vision of study program; the following vision study programs are written in accordance with the department's vision, the faculty vision and the university vision in the academic handbook of FTTE 2015/2016.

In curriculum also describes the vision, mission, products or the main services, the purpose of study program, the competency of graduates, the target of study program illustrated, graduate profile, the map of the graduates' competence (both professional competence, pedagogical, personality and social competence, all of which illustrate the ability of developing school programs and cooperation between schools/institutions either as individuals or groups associated with economic education, history and civics.

In FTTE Sriwijaya University, actually, Social Studies is a major in social studies curriculum does not mention individually but stated in each study program, a program of study economy, history and Civics Education. However, when examined from a third study program is exactly the same only 3 subjects, while the rest there are some who have in common is 14 subjects, whereas ano ther 5 subjects are compulsory subjects related to education.Next, the curriculum elaborates on the need for the curriculum development that should be adapted to the development: technology; science; social, cultural, economic, political, religious, and ecology related to learning courses of study program (understand widely and deeply the concepts, materials and methods of learning on the subjects of economics, history and civics) and (understand the concept and theories of economics and the field cognate studies.

FE Kochi University aims to produce outstanding teachers who can nurture the infinite potentials of human beings. It also aims to send forth graduates equipped with high degrees of specialized knowledge of their subjects and teaching skills based on extensive knowledge of their specialized fields. Social studies curriculum divided into six groups: first, History (total 20 credit semester), consisting of Introduction (2 credit semester) of four fields introduction of History (2 credit semester), Japanese History (Japanese History I, Japanese History II, Japanese History III (6 credit semester), Oriental History (Oriental History I, Oriental History II Oriental History III (6 sks), and Western History I, Western History II, Western History III (6 credit semester). Second is Geography (total 14 credit semester), consisting of Introduction to Geography and Topography ( 2 credit semester), i.e Geography I, II, III (6 credit semester), Topography I, II, III (6 credit semester). The third is Jurisprudence consisting of Introduction of Jurisprudence ( 2 credit semester), and Jurisprudence I, II, III (6 credit semester). Fourth is Political Science, consisting of Introduction to Political Science ( 2 credit semester), Political
Science I, II, III (6 credit semester), Fifth is Sociology, consisting of Introduction to Sociology (2 credit semester) and Sociology I, II, III (6 credit semester). Sixth is Economics (8 credit semester) consisting of Introduction to Economic and Political Economics (2 credit semester), and Economic Political Economy I, II, III ( 6 credit semester), and seventh is Philosophy (10 credit semester), consisting of Introduction to Philosophy (2 sks), Philosophy I, II, III ( 6 sks) and Ethics (2 sks). Students need to take more than 20 credit including 7 subjects so required for taking Teaching Profession Licence (Geography and History), and students need to take more than 20 credit including 3 subjects so required for taking Teaching Profession License.

SSE Department, as well as the purpose of the assessment conducted by Sriwijaya University and FTTE Sriwijaya University in general, which is to measure the achievement of the objectives that have been formulated in the curriculum. Assessment is done objectively to obtain a correct judgment through an assessment process during the lecture, the task giving (adjusted to the subject, such as practical work in the laboratory and into the field, or the same), written and oral quizzes, midterm exam and the final semester examination. After having assessed, the written examination papers should be returned to the students and the values of exam results announced openly to them.

Assessment systems are quizzes, test, assignment, and practice assessment of the lecture, practice in laboratories, quizzes, midterms and final exams are given in the form of numeric values on a scale of 0 until 100.The final value determined by a lecturer of the course, depending on the distribution of material provided. In general, the distribution was: $20 \%-35 \%$ of the value of lectures, assignments, laboratorium practice, quizzes; $20 \%$ - $40 \%$ of the value of midterms; $30 \%-45 \%$ of the value of final exams and lab; determination of final score. Determination of the final value of an academic activity carried out in order to evaluate the success of a student's study objectively based on the approach of Reference Benchmark Assessment. Under certain conditions, the determination of the final value may use Benchmark Reference Rate approach which combined with the approach of normal reference Assessment. Final Score is grouped into the categories of excellent, good, fair, less, and failed, and it is expressed in the form of grade letters A, B, C, D, and E.

Based on the triangulation results of the documentation results and interviews with the lecturer, both in SSE Department at FTTE Sriwijaya University as well as with lecturer and also served as dean of FE at Kochi University. The result showed that there are similarities and also differences in the curricula concept. The similarities are in terms of objectives, process, and the assessment, while in terms of content, especially in the review of the structure of the curricula there is a difference.

In the case of social studies curriculum in Indonesia, there is little difference between social studies curriculum in primary education up to university regulated in Japan. In Indonesia, the social studies curriculum in basic education, especially in primary schools is learned integrative in the form of thematic, whereas in Japan studied from grade 3 to grade 6. Social 
studies learning in junior high school in Indonesia have in common in Indonesia with social studies learned from grade VII until IX, in the form of integrated curricula. At the high school level, there are also similarities, which are separated studied subjects such as geography, history, and civics. The difference in Indonesia, social studies specifically studied more deeply in specialization in which is Social Studies Department. Although it has a little difference, but it seems that there are similarities in terms of the purpose of social studies, as proposed by [1] that: the Social Studies is the part of the elementary and high school curricula the which has the primary responsibility for helping students to develop the knowledge, skills, attitudes, and values needed to Participate in the civic life of reviews their local communities, the nation, and the world.

When the implementations of social studies curricula in Indonesia and in Japan are generally analyzed, then there are similarities; especially in junior and senior high school, in junior high school, social studies are taught in an integrative way while in high school, taught separately by the core of geography, economics, history, and civics. While at the elementary level, there is a little difference, meaning that in Indonesia (especially if associated with the implementation of curriculum 2013), social studies in Indonesia taught thematically, while in Japan the social studies concept started from grade 3 to grade 6 of elementary school.

Next, in terms of its objectives, Social studies of FTTE at Sriwijaya University is to produce teachers of social sciences (Economics, History, Civics Education) who are professional, master technology and information, and can compete globally, to develop research in the field of Social science education (Economics, History, Civics Education) and social sciences which resulted the information technology and the reformation of social sciences education, as well as carry out the devotion oriented to improving the quality of education social sciences (Economics, History, Civics Education) in accordance with the development and needs of the community. If we examine these three objectives of Social Studies above, including Tri Dharma Perguruan Tinggi (education and teaching, research and community service) because social studies education department still serves as a third shade of the subject. Meanwhile, particularly in Japan, social studies are not taught, except in FE at Kochi University, Social studies in university, there are no Social Studies for university students. But especially for Social studies students of FE Kochi University, Social studies' purposes are making good Social Studies teachers, who have knowledge, abilities, attitude, and skills as defined in Diploma Policy of Faculty of Education.

In terms of the content, social studies in SSE Department of FTTE Sriwijaya University, Indonesia with FE Kochi University, Japan, it can be said that it is specifically for a university degree. Social studies prevailing in SSE Department in FTTE Sriwijaya University, the curricula are designed in each of study program which is in Economics Education, History and Civics Study Program. From the three study programs, from each of a total of 144 credits, there are only 20 subjects which are similar and implemented in three courses (at SSE Department with the total number of 40 credits), however, of those subjects, from three study programs there are only nine subjects with the total of 25 credits. From those nine subjects, only four subjects that are the part of Social Studies subjects, as a social studies concept, theory, namely The Fundamentals of Geography, Social Education, Sociology, and Civics

Meanwhile in FE, Kochi University, from 149 credits contained in the curricula, if classified, it generally consists of four major groups of subjects of history. These courses consist of namely Japanese, Oriental History, and Western History, with total credits of 20 credits. Furthermore, the second group is the subject of Geography and Topography of six credits, the third group that is Jurisprudence, Political Philosophy, and Ethics, with a total of 32 credits. If they are grouped, they become the part of a clump of Civic Education subjects. Next is a group Sociology of subjects consisting of 8 credits, and 8 credits of Economics subject.

Next, in the terms of social studies learning the process, social studies are done by using a variety of learning methods and multi-way, including lectures, discussion method, question and answer method, project method, a method of travel works, role-playing and demonstration methods. To support some of the above methods, the learning model is used including a model of cooperative learning, inquiry learning model, VCT (Value Clarification Technique) learning models, STS approach (Science-Technology-Society) Role Play and learning model. While in Faculty of Education, Kochi University, Social Science learning is done in one directional.

In the planning, the lecturer has prepared well on the syllabus, lesson plans, instructional media, and student worksheets. It was identified from documentation syllabus, lesson plans, instructional media, and student worksheets that were made/ prepared by lecturers. Each student was required to have, read, understand handbook that has been recommended by lecturers for the course. At the first time of the process of learning in the classroom, lecturer entered the classroom after students were already in classrooms although there were still some students who were a little late for class. Lecturer went straight to the front of the class and prepared handouts and worksheets for student learning by putting the handout on the table in front of the class. Without orders, the students took handouts and worksheets in turn and went back into the seat.

At this stage of core activities, after a student got handout and worksheets directly, lecturer delivered the learning material. Lecturer began to explain the learning material from slide to slide, students were sitting in their seat orderly. In general, students were serious and directly involved mentally active (thinking) about the material that is discussed. Lecturer implemented based on the plan that already in accordance with the competence to be achieved. The learning is holistic, learning material is always associated with the context of everyday life. However, the learning process seemed lecturer dominated (teacher centered). Student activity just listening, listened to what was being said by the lecturer, they responded by writing the lecturer's explanation in the handout, openingreading the source of reading books without any attempts to ask questions or give comment on the material being discussed. Instructional media used was power point-slide with black or white, and red color for the very important concept. Slide variation is limited to text, without any graphic or image on 
learning materials. Learning resources used is a reference book/handout for lecturers and students. The book has been recommended by a lecturer in which includes user manuals, lecture material, as well as the details of the tasks that should be done by the students during the lecture (one semester). The learning process was carried out according to the planned time allocation, i.e $2 \times 45$ minutes and the learning ended at 15.00.

The process of learning of social studies subjects in FE Kochi University in Japan was conducted as many as 16 sessions in one semester. Each meeting was done within 90 minutes. Thus the schedule and the time allocated to each meeting has been agreed according to applicable regulations. Information obtained relating to the agreement classroom discipline, which was present on time, the tasks performed, and the clothing for students is basically no provisions that are allowed as long as it is comfortable to wear. Results of observation of the learning process, it is known that the lecturer at the beginning, the core, and the end of the lesson is always in front of the class, while students still sit in his seat each. The parallel arrangement of the seating rows was from front to back. Lecturer and students during the learning were always faced. It was possible to carry out learning activities in the classroom. Instructional media of computers and LCD projectors were already available in the classroom so that the lecturer was ready to use them. Structuring of the learning environment was identified and held in the classroom, but, if there are tasks that must be done by the students outside the classroom context, it can be done.

At the beginning of the learning activities and during the learning process in the classroom, the assessment process of cognitive, affective, and psychomotor aspects was not identified. At the end of the learning activity, students were given questions to be answered and the answers were directly collected, but still, the students were not given the opportunity to ask questions to the lecturer. Students answered the questions on the worksheet that they have acquired at the beginning of learning based on their understanding of each as a result of the learning process. If there was a statement in the learning process/ problems faced by the students, then the question on an individual basis in consultation with the lecturer would be discussed at a specified time in accordance with the agreements approved by the lecturer and students.From the observation result, it was known that the assessment process was done after the process of learning in the classroom through the results of individual and group tasks, group presentations, and exam results.

Based on triangulation among the results of observation with interviews and documentation used at the time of the study, it was indeed that at the lecturer began to give the lecture, while at the next time, the lecturer will ask the students to make a lesson plan associated with the first lecture. If it is associated with the notion that learning activities are the "heart" of the curriculum, it is because they influence the formation of students' learning experiences and educational outcomes. Ref. [13] states that "learning experiences and not the content as such, are the means for achieving all objectives besides reviews, those of knowledge and understanding". In a functional curriculum, content and learning activities have a relationship and a unity, as stated by [10] that "when students engage in studying, learning, constructing, analyzing, feeling, thinking, etc, they must utilize some contents: i.e they study something, learn something, think something, and so on, furthermore, it is said that the main standard in selecting and determining the activities to learn is how various learning activities can contribute to the achievement of the objectives of the curriculum outcomes, the aims, goals, and objectives.

In terms of evaluation, which is applicable in SSE Department of FTTE Sriwijaya University, in evaluating social studies learning is done by looking at three aspects, namely the cognitive aspects related to the knowledge of learners, effective aspects associated with the attitude of learners, and psychomotor aspects related to skills of learners. To support these three aspects classroom-based assessment can be used, by using a variety of assessment techniques, including; performance assessment, project assessment, product assessment, assessment of written tests, portfolio assessment, attitude assessment and self-assessment. Seven assessment techniques can be adapted to the needs assessment of three aspects mentioned above. In the implementation, assessment is carried out at least three times that comes from assignments, midterms and final exams. For the assessment of duties, usually in the form of a portfolio, such as making paper, document analysis, observation, test instruments and others according to the course of teaching.

While in FE Kochi University, the assessment was almost synonymous which is also made into three aspects of cognitive, affective and psychomotor. In other words, the evaluation is likely to lead to the evaluation of learning outcomes, as indicated by [13] that the evaluation of the curriculum is often viewed simply as an evaluation of student achievement (product achievement) associated with "figures", which is to determine whether the goals have been achieved, as stated by [13] that: the focus of evaluation is principal of "the degree to which pupils attain ... objectives.

Regarding the implementation of social studies curriculum in Indonesia and Japan, it can be seen from the observation, which indicates that the implementations of social studies learning in Indonesia and Japan are not much different, it means that the implementation is classical and the learning process is done by using LCD as a medium and power point as the slide. The initial implementation of the lecture is mostly done by the lecturer by providing expository material in a way, starting with the initial explanation, showing the power point and ending with the provision of the question in the form of handouts. Then the administration tasks are performed after the learning process in the classroom through the results of individual and group tasks, group presentations, and results in exam

Based on triangulation between the results of observation with interviews and documentation used at the time of the study, it was observed that the lecture at the first meeting (inaugural lecture) was conducted by the lecturer. Thus, lecturer implemented more the instructional that provides information (expository). At the next time, the lecturer will ask the student to make a lesson plan related to the inaugural lecture. If it is associated with the notion that learning activities are the "heart" of the curriculum because they influence the 
formation of students' learning experiences and educational outcomes. Ref. [13] states that "learning experiences, and not the content as such, are the means for achieving all objectives besides reviews those of knowledge and understanding". In a functional curriculum, content and learning activities have a relationship and a unity, as stated by [10] that "when students engage in studying, learning, constructing, analyzing, feeling, thinking, etc, they must utilize some content: i.e they study something, learn something, think something, and so on, furthermore, it is said that the main standard in selecting and determining the activities to learn is how various learning activities can contribute to the achievement of the objectives of the curricula outcomes, the aims, goals and objectives.

Related to the perception of social studies students against the curriculum, social studies learning and social studies lesson in junior high school. Furthermore, the perception of Indonesian students in Japan on Social Studies subjects can be described as follows:

Based on the opinion of $51 \%$ Indonesian student respondents stated strongly agree, while $50 \%$ of Japanese students agreed that social study course aims to make pertinent as a good citizen. Based on the opinion of $54 \%$ Indonesian student respondents stated strongly agree and $50 \%$ said the Japanese students strongly agreed that the course was very useful for a future social studies teacher. Based on the opinion of $48 \%$ Indonesian student respondents stated strongly disagree, while the Japanese students $33 \%$ did not agree that not all students have to study social studies subjects. Next, $50 \%$ Indonesian student respondents stated strongly agree, while the Japanese students $45.8 \%$ disagree with the statement that social studies subjects are necessary for all students in all majors. Based on the opinion of $62 \%$ Indonesian student respondents stated strongly agree, while $45.8 \%$ of Japanese students agreed that the social subjects should be fun. Next, 52\% Indonesian student respondents stated strongly disagree, while $54.2 \%$ of Japanese students stated disagree that social studies course are sufficiently mastered by memorizing. Based on the opinion of $59 \%$ respondents of Indonesian students stated strongly agree, while $45.8 \%$ of Japanese students hesitated that they were pleased to learn the subject because they really enjoy social studies. Based on the opinion of $34 \%$ Indonesian students stated strongly disagree, while $50 \%$ of Japanese students expressed doubt that the portion/number of social studies subjects are lacking for supporting their profession as a teacher (Economics /Civics/ History). Based on the opinion of 38\% respondents of Indonesian students stated strongly agree, while $54.2 \%$ of Japanese students disagree that the number of credits social studies subjects should be greater than the number of credits now. Based on the opinion of $61 \%$ Indonesian student respondents stated strongly agree, while $41.7 \%$ of Japanese students expressed doubt that they were quite confident with the provision of social studies lectures that they received during the lecture.

Regarding the students' perceptions from social studies education at FTTE Sriwijaya University with students of FE in Kochi University Japan on learning social studies, as follows:

Based on the opinion of $61 \%$ Indonesian students stated strongly agree, while $50 \%$ of Japanese students agreed that the lecture of social studies subject was fun. Furthermore, in the opinion of $53 \%$, Indonesian students of respondents stated strongly disagree, while $45 \%$ of Japanese students disagree that social studies lecture was boring. Based on the opinion of $28 \%$ Indonesian students stated strongly disagree, while $50 \%$ of Japanese students expressed doubt that social studies subjects should be made easier. Based on the opinion of $52 \%$ Indonesian students stated strongly agree and $50 \%$ of Japanese students agreed that social studies lecture would be fun if it was implemented by way of a direct visit to the real conditions in the field. Moreover, 52\% Indonesian students of respondents stated strongly agree and $58.3 \%$ of Japanese students agreed that social studies lecture was fun if lecturer did the interactive learning methods. Based on the opinion of $48 \%$ Indonesian student respondents stated strongly agree and $41.7 \%$ of Japanese students agreed that social studies lecture was fun when learning was centered on the student (student-centered learning). Based on the opinion of $59 \%$ Indonesian student respondents stated strongly agree, while $45.8 \%$ of Japanese students expressed doubt that social studies course encourage them to think critically.

Based on the opinion of $60 \%$ of Indonesian student respondents stated strongly agreed, while $58.3 \%$ of Japanese students expressed hesitated when the social studies material delivered by lecturer were easily understood. Based on the opinion of $62 \%$ Indonesian students of respondents stated strongly agree and $37.5 \%$ of Japanese students expressed doubt that social studies were fun, as lecturer presented it in an interesting way. Based on the opinion of $51 \%$ Indonesian student respondents stated strongly agree, while $58.3 \%$ of Japanese students expressed doubt that social studies subjects were easier to understand than the other subjects. Next, $66 \%$ Indonesian student respondents stated strongly agree and $54.2 \%$ of Japanese students agreed that the lecturer of social studies subject was able to manage a class. Based on the opinion of $31 \%$ Indonesian student respondents stated strongly agree, while $41.7 \%$ of Japanese students agreed that it was better if the class management of social studies classes was done by arranging the sitting position. Based on the opinion of $46 \%$ Indonesian student respondents stated strongly agree, while $54.2 \%$ of Japanese students agreed that social studies lecture was fun if using the appropriate learning media. Based on the opinion of $32 \%$ Indonesian student respondents stated strongly agree, while $45.8 \%$ of Japanese students expressed doubt that social studies subject was boring because it only used power point.

Based on the opinion of $54 \%$ Indonesian student respondents stated strongly agree, while $41.7 \%$ of Japanese students expressed doubt that social studies subject was fun because the lecturer used varied instructional media. Based on the opinion of $52 \%$ Indonesian student respondents stated strongly disagree and $37.5 \%$ of Japanese students study subjects agreed that social studies were simply learned by reading social studies books only. Based on the opinion of $47 \%$ Indonesian student respondents stated strongly agree, while $45.8 \%$ of Japanese students agreed that the assessment of social studies learning must be comprehensive (affective, cognitive and psychomotor). Based on the opinion of $40 \%$ Indonesian student respondents stated strongly disagree, while $50 \%$ of 
Japanese students disagree that the assessment of social studies subject was not only from the results of the assessment. Next, $46 \%$ Indonesian student respondents stated strongly agree, while $58.3 \%$ of Japanese students expressed doubt that social studies subject had a transparent assessment. Based on the opinion of $55 \%$ Indonesian student respondents stated strongly agree and $41.7 \%$ of Japanese students agreed that the assessment of social studies subject was accountable.

Furthermore, the students' perceptions of social studies lesson at schools from students majoring in SSE of FTTE and FEKochi University as follows:

Based on the opinion of $57 \%$ Indonesian student respondents stated strongly agree and $50 \%$ of Japanese students agreed that social studies lesson in junior high school was the blend of a field study of geography, sociology, economics, and history. Based on the opinion of $52 \%$ Indonesian student respondents stated strongly agree, $41.7 \%$ while the Japanese students expressed doubt that social studies lesson aims to make students become good social citizens. Based on the opinion of $54 \%$ Indonesian student respondents stated strongly agree, while $37.5 \%$ of Japanese students expressed doubt that junior high school social studies lesson required students to think critically. Next, 35\% Indonesian student respondents stated strongly disagree, while $37.5 \%$ of Japanese students expressed doubt that the students who successfully learn social studies can memorize the social studies material. Based on the opinion of $66 \%$ Indonesian student respondents stated strongly agree, while $45.8 \%$ expressed doubt that the form of social studies learning had the umbrella theme of four studies examined namely geography, sociology, economics and history.

Based on the opinion of $62 \%$ Indonesian student respondents stated strongly agree, while $54.2 \%$ of students expressed doubt that social studies lesson in junior high social was formulated on the basis of reality and social phenomenon that embodies the interdisciplinary approach of aspects and branches of social sciences. Based on the opinion of $55 \%$ Indonesian student respondents stated strongly agree, while $50 \%$ of Japanese students expressed doubt that social studies lesson in Indonesia emphasis on the knowledge of the people, the spirit of nationalism, socialism, as well as community activities in the economic field in space or space The Unitary State of the Republic of Indonesia **).

Based on the opinion of $47 \%$ Indonesian student respondents stated strongly agree and $58.3 \%$ of Japanese students agreed that social studies were developed as an integrative social studies subjects, not as educational disciplines. Based on the opinion of $64 \%$ Indonesian student respondents stated strongly agree, while $62.5 \%$ of Japanese students expressed doubt that the social studies lesson related to various social problems that are formulated with an interdisciplinary and multidisciplinary approach. Based on the opinion of $56 \%$ Indonesian student respondents stated strongly agree, while $58.3 \%$ of Japanese students expressed doubt that the assessment of social studies in junior high school should comprehensively test the ability of cognitive, affective and psychomotor.
Based on the opinions of respondents of lecturer of Japan, it can be seen that the most obstacles when teaching the social studies subject namely: a) knowledge of the students varied, b) deviation between subjects and curriculum, and c) adjusting student learning and development. The means used to overcome obstacles when teaching social studies subject by lecturers in Japan, namely: a) describes the return of material to students whose knowledge is lacking, b) increasing the activity of students in participating in the learning process, and c) the ability of lecturers needs to be improved to provide learning materials to conform to the curriculum will be achieved. Moreover, it can be known social studies which are being or has been done has been good, in terms of curriculum, instructional media, educators, facilities and infrastructure. The suggestions given by Japanese lecturer against the social studies subjects given by lecturers, namely: a) it is better if the learning methods used according to the characteristics of students (elementary, junior high, high school and university), and b) should have the experience and knowledge of the student and curriculum needs to be enhanced.

The obstacles experienced by students in learning social studies that are:: a) the material is too much and too broad, b) the material is considered difficult, c) the lack of field practice, d) the number of terms used, e) lack of facilities, f) learning activities focused on power point) the teacher explains the material too fast, h) and a noisy classroom atmosphere. While from Japanese students, it can be known that the most experienced obstacles when following social studies lecture were as many as 18 people (75\%). Obstacles experienced are: a) lack of concentration, activity and learning motivation of students while attending the learning process, b) social studies so much that nothing is taken simultaneously, c) learning materials IPS difficult to understand because it does not demonstrate concretely, d) students have difficulty in answering questions during the test (test), e) lack of ability of teachers to do a variety of teaching such as teaching methods that tend to use the lecture method.

The ways used to overcome the obstacles when having social studies lecture by Indonesian university students, namely: a) self-learning through a variety of sources, b) resume material, c) field visits, d) teachers teaching with a variety of methods, e) and the current focus of learning activities, while the ways used to overcome obstacles while following social studies lecture by Japanese students are: a) for students to understand social studies in addition to classroom learning, students should learn independently and exchanged ideas in group discussion activities, b) to address social studies subjects that is too much, it needs to regulate the subjects taken in each semester, and c) the ability of teachers also needs to be improved in delivering learning materials.

While, according to Indonesian student respondents, it can be known that there is already a good thing in learning social studies which are being pursued, namely: a) curriculum, b) the ability of teachers in presenting the material, c) the methods used during the learning process, and d) the ability to manage the class. Things that are not good enough is about learning social studies that are being pursued, namely: a) room facilities (ac, fan, narrow place), b) facilities that support learning activities (LCD, internet) c) and lecturers who teach in a 
monotonous way. Next, according to Japanese student respondents, it is known that social studies learning which is being pursued are quite good in terms of the curriculum, and evaluation processes, and facilities. Students who have a good opinion about social studies learning on the part of the curriculum which is the evaluation (test) still does not show the progress of from participating the social education subject from the middle to the top because not all the subject matters can be submitted through the exam.

The suggestions given by Indonesian students on social studies, are: a) improving the facilities and infrastructure in the learning activities, b) using methods and instructional media were varied and not monotonous, c) conducting site visits to the field in order to understand more the learning, d) creating a pleasant atmosphere during the learning process, e) and performing the learning activities in groups. While the suggestions given by the Japanese students on social studies, are: a) in following social studies, the group formed by diverse characteristics of students so that all students can work in groups, and b) in learning process, students are not only taught about the theory, but also the practice in social studies,i.e performing simulations.

How to overcome these problems, namely: a) for students to understand social studies in addition to classroom learning, they should learn independently and exchanged ideas in group discussion activities, b) to overcome social studies subject which are too much, the regulation of the subjects that should be taken in each semester is needed, and c) the ability of teachers also needs to be improved in delivering learning materials.

\section{CONCLUSION AND RECOMMENDATION}

There are some similarities between the concept of the curriculum in Indonesia and in Japan especially in middle and high school level (in Japan their subjects are geography, history, and civics), while at the primary level, if in Indonesia starting from the first class, while in Japan starting in grade 3. The goal of SSE Department of FTTE US is to produce social sciences educators (Economics, History, Civics). The three subjects of economics, history, and civics are still partial because social studies education is majoring those three study programs. Meanwhile, in Japan, especially in university, social studies are not taught, except in FE at Kochi University. Social studies purposes are making good Social Studies teachers, who have knowledge, abilities, attitude, and skills as defined in Diploma Policy of FE. In terms of content designed in the curriculum of each study program (Economic Education, History and Civics), the total of credits is 144 credits, of which only nine subjects are the same, and in accordance with the concept of Social Studies theory, the only course of Fundamentals of Geography, Social Education, Sociology, and Civics. In FE, University Kochi there are 149 credits, which are grouped into four major groups of history, GeographyTopography jurisprudence, Politics, Philosophy and Ethics subjects. Next is a group of Sociology and Economics subjects.

In terms of process, FTTE Sriwijaya University uses a variety of learning methods and multi-ways, while at FE, Kochi University, Social Science learned more unidirectional. Implementations of learning in both faculties are classical. The learning process is done by LCD media and power point. At the beginning of the lecture, the lecturers are dominant, give expository material by watching a power point, and end with the provision of the question in the form of handouts, students do some individual assignments, group presentations, etc. Moreover, they agree if not all students have to study SS subjects. They enjoy learning social studies and would be happy if the lecture is fun by using a variety of methods, as well as the appropriate media. The students also agree if the lecturers who proponent the social studies subject can manage the class well. Thus, almost half of them agree if the social studies learning have student-centered learning, so they also agree if the assessment should be comprehensive and accountable. The results showed that there are some students of Japan who answer hesitantly, while Sriwijaya University students agree to the statement that social studies subjects can make students thinks critically, material presented by lecturer is easily understood, social studies are fun, and assessment social studies subject is tangible, even Kochi students agree if social studies learned only from books, while Sriwijaya University students clearly state strongly disagree with the statement. Kochi students also generally answer that they are doubt on the assertion that the purpose of social studies is to make students become good citizens, capable of making critical students, social studies in junior high school are formulated on the interdisciplinary phenomenon, these subjects are about national and social, the assessment is also comprehensive.

The obstacles of Sriwijaya University lecturers are classroom atmosphere is unfavorable due to the inadequate classroom is seen from a comparison of broad classes with many students, the lack of teaching facilities such as airconditioning, projector, fan, and others. There is a density of material so that the lecturer has difficulty in sorting out the course material. Students' obstacles, among others, the material is too much and wide, while the lecturer explains it too fast by using one method only (lecture), supported also by the less conducive atmosphere so students are lack of concentration. There is also a lack of field practice. The way to overcome them is that they generally do self-learning through a variety of sources, and discussion among students. Another way is to conduct field visits.

Obstacles that Japanese lecturers have when teaching social studies subject are the various levels of knowledge of students, the deviation between the subject and curriculum. Ways in which to overcome is the lecturer re-explains the material which is not yet understood by the student, and also to increase the activity of students in following the learning process. In addition, lecturer also needs to improve the ability to provide learning materials to fit the curriculum that will be achieved. The obstacles of students in learning social studies are their evaluation does not show the progress of the subject that has been followed since the evaluation does not represent all of the subject matters that has been studied.

\section{ACKNOWLEDGMENT}

We would like to thanks the Dean and Vices of Dean of Faculty of Teacher and Training Education, Sriwijaya University for giving Competitive Grant Research Fund and 
The Dean of Faculty Education, Kochi University Japan for collaborating in this research

\section{REFERENCES}

[1] Banks, James A. (1985). Teaching Strategies For The Social Studies, New York and London: Longman.

[2] The National Council for the Social Studies (NCSS), 1983 dan 1994

[3] Kamarga, Hansiswany. 2000. Model Pembelajaran Pengemas Awal (Advance Organizers) Dalam Implementasi Kurikulum Sejarah yang menggunakan Pendekatan Kronologis dalam rangka Mengembangkan Aspek berfikir Kesejarahan. Disertasi Program Pascasarjana UPI, Bandung: Tidak dipublikasikan.

[4] Sanusi, A. (1998). Pendidikan Alternatif: Menyentuh Azas Dasar Persoalan Pendidikan dan Kemasyarakatan, Bandung: Grafindo Media Pratama.

[5] Hasan, Hamid, S. (2008). Evaluasi Kurikulum. Bandung: Rosda Karya
[6] Al Muchtar, Suwarma. (2001). Pendidikan dan Masalah Sosial Budaya, Bandung: Gelar Pustaka Mandiri.

[7] Somantri, Nu'man. (2001). Menggagas Pembaharuan Pendidikan IPS. (Editor Dedi Supriadi dan Rochmat Mulyana), Bandung: Remaja Rosdakarya, Bandung.

[8] Beauchamp, George A. (1975). Curriculum Theory. Wilmette, Illinois: The KAGG Press.

[9] Johnson, Mauritz. (1977). Intentionality in Education. New York: Center for Curriculum Research and Services.

[10] Zais, Robert S., 1976, Curriculum Principes and Foundation, Harper \& Row Publisher

[11] NCSS. (1983). Curriculum Standards for Social Studies. Washington.

[12] Winataputra, Udin. S. (2007). Dinamika Pemikiran Inovatif Dalam Khasanah Social Studies dan Pendidikan Ilmu Pengetahuan Sosial (IPS) Untuk Pendidikan Dasar dan Menengah di Indonesia, Makalah: Disampaikan dalam Seminar Nasional Pendidikan IPS tanggal 21 November 2007 di Auditorium JICA-UPI.

[13] Taba, Hilda. (1962). Curriculum Development: Theory and Practices, New York: Harcourt, Brace and World, Inc. 